Jurnal Interpretasi Hukum | ISSN: 2746-5047

Vol. 2, No. 3-Desember 2021, Hal. 573-579| Tersedia online di

https://www.ejournal.warmadewa.ac.id/index.php/juinhum

DOI: https://doi.org/10.22225/juinhum.2.3.4139.573-579

\title{
PROSEDUR PENGEMBALIAN DAN PEMULIHAN KERUGIAN NEGARA AKIBAT TINDAK PIDANA KORUPSI
}

\author{
Sandi Herintus Kabba, I Made Arjaya, I Made Minggu Widyantara \\ Fakultas Hukum, Universitas Warmadewa, Denpasar-Bali, Indonesia \\ sandikabba17@gmail.com, imd.arjaya@gmail.com, mademinggu21@gmail.com
}

\begin{abstract}
Abstrak
Korupsi merupakan kejahatan luar biasa yang pemberantasan harus dilakukan dengan cara yang luar biasa pula sesuai prosedur pengembalian dan pemulihan kerugian Negara akibat korupsi. Tujuan penelitian ini untuk mengungkapkan proses pelaksanaan pengembalian dan pemulihan kerugian negara oleh jaksa pada tindak pidana korupsi serta upaya pengembalian dan pemulihan kerugian negara akibat korupsi. Metode yang digunakan adalah penelitian hukum normatif dengan pendekatan perundang-undangan dan pendekatan konseptual. Teknik pengumpulan bahan hukum dilakukan melalui studi pencatatan dan dokumentasi. Sumber bahan hukum primer dan sekunder digunakan sebagai sumber bahan-bahan hukum dalam studi ini. Kemudian, bahan dan data hukum tersebut dikelola dengan menggunakan analisis interpretasi. Hasil Penelitian mengungkapkan bahwa prosedur pengembalian dan pemulihan kerugian negara akibat tindak pidana korupsi sudah sesuai prosedurnya yaitu Undang-undang pemberantasan korupsi dan peraturan lainnya. upaya pengembalian dan pemulihan kerugian Negara Akibat korupsi dengan memaksimalkan pengembalian kerugian Negara dengan upaya penyitaan, penelusuran harta kekayaan milik terpidana, kewenangan Jaksa KPK harus diatur secara tegas dan jelas. Penulis menyarankan Pemerintah harus memberikan sarana dan prasarana yang cukup bagi Kejaksaan dan KPK dalam rangka memaksimalkan pemberantasan korupsi, masyarakat perlu menyampaikan informasi ke Kejaksaan, KPK, dan Kepolisian terkait tindak pidana korupsi yang terjadi.
\end{abstract}

Kata Kunci: Kerugian Negara, Prosedur Pengembalian, Tindak Pidana korupsi.

\begin{abstract}
Corruption is an extraordinary crime whose eradication must be carried out in an extraordinary manner according to the procedures for returning and recovering state losses due to corruption. The purposes of this study are to reveal the process of implementing the return and recovery of state losses by prosecutors on corruption crimes as well as efforts to restore and recover state losses due to corruption. The method used is normative legal research with a statutory approach and a conceptual approach. The technique of collecting legal materials is done through the study of recording and documentation. Primary and secondary sources of legal materials are used as sources of legal materials in this study. Then, the legal materials and data are managed using interpretation analysis. The results of the study reveal that the procedure for returning and recovering state losses due to corruption is in accordance with the procedures, namely the Law on the Eradication of Corruption and other regulations. efforts to recover and recover state losses due to corruption by maximizing the return of state losses by confiscation, tracing the assets of the convict, the authority of the $K P K$ prosecutor must be regulated firmly and clearly. The author suggests that the Government should provide adequate facilities and infrastructure for the Prosecutor's Office and the KPK in order to maximize the eradication of corruption, the public needs to submit information to the Prosecutor's Office, the KPK, and the Police regarding corruption crimes that have occurred.
\end{abstract}

Keywords: State Losses, Return Procedure, Corruption Crime.

\section{PENDAHULUAN}

Kasus korupsi tidak lepas dari pemberitaan yang disuguhkan oleh media cetak dan media elektronik. Baik perkembangan kasus korupsi yang baru muncul, yang sedang diproses oleh para penegak hukum dan yang telah terungkap penegak hukum. Pemberitaan soal korupsi tersebut seakan-akan telah menjadi sarapan di waktu pagi hari hingga makan malam saat menjelang tidur. Adanya reaksi masyarakat yang menghujat para koruptor dan reaksi para pakar hukum serta berbagai pihak yang berspekulasi mengenai penyebab korupsi, mengenai bahaya korupsi bahkan jaringan korupsi yang semakin meluas dan merajalela telah membuat semakin menarik perhatian publik untuk mengikuti perkembangan-perkembangan perkara korupsi di Indonesia. 
Extraordinary crime atau kejahatan yang luar biasa, korupsi sebagai tindakan yang disebabkan tindak pidana korupsi tidak saja sebagai masalah yang dihadapi satu negara namun juga sebagai masalah internasional yang dihadapi banyak negara di dunia. Bukan saja dihadapi oleh negara-negara maju, bahkan kasus korupsi ini banyak dan menjadi ancaman bagi negara-negara berkembang di seluruh belahan dunia. oleh sebab itu kerjasama secara aktif dilakukan oleh banyak negara untuk memberantas tindak pidana korupsi ini.

Negara-negara di dunia pun mengakui bahwa yang sangat merugikan dan mempunyai dampak buruk bagi perekonomian suatu negara adalah korupsi, karena itu dapat menurunkan standar hidup rakyat suatu negara, menghambat pertumbuhan ekonomi, dan pembengkakan defisit anggaran belanja negara. Pada tahun 2003 United Nations Convention Against Corruption (UNCAC) menerbitkan ini untuk menjawab keresahan yang ditimbulkan tindak pidana korupsi. dengan UU Nomor 7 Tahun 2006 tentang Pengesahan United Nations Convention Against Corruption, 2003 (Konvensi Perserikatan Bangsa-Bangsa Anti Korupsi, 2003), dengan itu Indonesia sudah meratifikasi konvensi tersebut, yang artinya berkomitmen dan mendukung dalam upaya pemberantasan, mencegah dan meniadakan praktik korupsi serta secara politis Indonesia telah memposisikan dirinya. Akan menyebabkan bencana serius bukan saja berkaitan dengan kehidupan ekonomi nasional suatu negara namun juga bagi kehidupan dalam berbangsa dan bernegara apabila tindak pidana korupsi yang tidak dikendalikan, dengan meluasnya dan sistematisnya tindak pidana korupsi yang juga adalah pelanggaran mengenai hak ekonomi warga masyarakat dan hak-hak sosialnya, oleh sebab itu tak bisa dikategorikan sebagai kejahatan yang biasa korupsi ini melainkan menjadi suatu kejahatan yang extra ordinary. Sehingga proses pemberantasannya pun tidak dapat lagi dilaksanakan dengan biasa, melainkan dengan upaya dan proses luar biasa.

Negara Indonesia adalah Negara hukum seperti yang di jabarkan Undang-undang Dasar Negara Republik Indonesia Tahun 1945 tepatnya Pasal 1 ayat (3). Kandungan makna yang terkandung dalam pengertian negara hukum pada prinsipnya yaitu kebijakan yang diambil negara ke arah mana untuk menyongsong kehidupan berbangsa dan bernegara. Dari prinsip inilah yang melatarbelakangi Undang-undang Nomor 31 Tahun 1999 jo Undang-undang Nomor 20 Tahun 2001 Tentang Perubahannya yang terlahir. Isu pokok, mengenai Perkembangan pemberantasan korupsi saat ini telah berfokus pada tiga hal yaitu mencegah, memberantas dan pembayaran uang pengganti/mengembalikan kerugian Negara. Hal ini menjabarkan bahwasanya upaya pemberantasan korupsi bukan hanya terletak pada upaya mencegah serta memberantas dalam hal memidanakan pelaku saja tetapi juga berkaitan dengan upaya mengembalikan dan memulihkan kerugian Negara dari hasil tindak pidana korupsi. Pengembalian kerugian keuangan negara dapat dilakukan melalui dua instrument hukum yaitu instrument pidana dan instrument perdata (Arifin, 2019). Upaya pengembalian aset merupakan suatu proses yang sulit, bahkan dalam keadaan yang ideal sekalipun, upaya pengembalian aset merupakan proses kompleks dan multidisiplin (Candra \& Arfin, 2018). Pengembalian kerugian Negara tersebut tidak memberikan dampak yang lebih buruk lagi dan dimaksudkan agar kerugian negara yang timbul dapat ditutupi oleh pengembalian dan pemulihan dari hasil korupsi itu.

Di Indonesia, penegakan hukum terus ditingkatkan dan menjadi prioritas utama bagi penegak hukum khususnya polisi jaksa dan Komisi Pemberantasan Korupsi (KPK) terutama berkenaan tindakan korupsi dalam mengungkap kasus korupsi yang muncul dan terjadi di bumi Indonesia saat ini. tahap penyidikan yang dilakukan oleh penegak hukum mengenai pengungkapan kasus-kasus korupsi dan sangat bergantung dengan memaksimalkan upaya-upaya membongkar kasus korupsi yang dilakukan penegak hukum dengan wewenang yang dimiliki berdasarkan peraturan perundangundangan serta didukung sarana dan prasarana sehingga pengembalian uang kerugian negara dari tindak pidana korupsi bisa dilakukan secara maksimal. Upaya dalam mengembalikan kerugian uang negara pada tindak pidana korupsi adalah pemulihan kerugian uang yang dialami negara yang dalam kenyataannya masih terdapat beberapa hambatan dalam pelaksanaanya baik dalam tahapan prosedur maupun pada tahapan teknis (Saidi, 2011). Instrumen-instrumen yang sesuai dengan modus tindak pidana ini dan obyek masalah hukumnya ini ada dalam tataran prosedural. hasil dari kasus tindak pidana korupsi berupa uang negara kenyataanya tidak saja dinikmati oleh pelaku/terdakwa, namun juga dinikmati dan diterima pihak ketiga yang tidak menjadi terpidana. upaya mengembalikan kerugian keuangan negara dari pihak ketiga secara prosedur membutuhkan tindakan hukum yang pas 
serta efektif (Musahib, 2015). Karena tak diatur secara rinci mengenai penggantian pembayaran uang yang tidak dibayar sepenuhnya oleh terdakwa.

Adapun penelitian sebelumnya dari Mahmud (2018) yang meneliti kerugian materiil yang diderita Dinas Kependudukan dan Catatan Sipil Kabupaten Indragiri Hulu. Putusan Nomor 62/Pid.Sus/Tipikor/2013/ PN.PBR belum mampu mengembalikan kerugian negara/daerah sebagai korban karena tidak memberikan pemulihan (restorasi) terhadap kerugian tersebut. hakim mengabaikan laporan hasil investigasi Badan Pengawasan Keuangan dan Pembangunan yang menunjukkan adanya kerugian keuangan daerah senilai $\mathrm{Rp} 960.386 .000$ dan terdakwa hanya dijatuhkan pidana penjara dan denda. Sedangkan penelitian dari Hersriavita (2019) mengungkapkan upaya yang dilakukan Kejaksaan Negeri Sukoharjo dalam memaksimalkan pengembalian kerugian negara dalam perkara tindak pidana korupsi adalah pembenahan dari substansi hukum itu sendiri yang dilakukan dengan melakukan koordinasi dengan berbagai sumber pelaksana hukum dan sasaran kepada masyarakat sebagai tujuan kebijakan dalam upaya pengembalian kerugian keuangan negara mengoptimalkan mekanisme proses penyidikan dengan koordinasi dengan berbagai pihak yang terkait. Lebih lanjut, berdasarkan regulasi terkait pengembalian kerugian negara di masa yang akan datang yaitu dengan melakukan revisi terhadap ketentuan Pasal 18 Ayat (3) Undang-undang Nomor 31 Tahun 1999 Jo. Undang-undang Nomor 20 Tahun 2001 Tentang Pemberantasan Tindak Pidana Korupsi serta menambahkan ketentuan dalam Pasal 10 KUHP dalam pidana pokok berupa pengembalian kerugian keuangan negara (Darmawati, 2020). Dari fenomena tersebut maka dilakukannya penelitian yang bertujuan untuk mengungkapkan proses pelaksanaan pengembalian dan pemulihan kerugian negara oleh jaksa pada tindak pidana korupsi serta upaya pengembalian dan pemulihan kerugian negara akibat korupsi.

\section{METODE PENELITIAN}

Penelitian ini menggunakan tipe penelitian hukum normatif yang meletakan aturan menjadi bangunan sistem norma sebagai metode penelitian dalam studi ini yakni mengenai asas-asas hukum, doktrin, norma-norma, kaidah-kaidah terhadap suatu peraturan undang-undang dengan pendekatan perundangundangan dan pendekatan konseptual. Peneliti menemukan bahan hukum yang diperlukan sebagai penunjang penelitian ini dengan menggunakan teknik studi pencatatan dan dokumentasi. Sumber bahan-bahan hukum sekunder dan primer dipergunakan sebagai Sumber bahan hukum dalam studi ini. Bahan hukum yang telah berhubungan dengan permasalahan telah terkumpul. Kemudian, bahan dan data hukum tersebut dikelola dengan menggunakan analisis interpretasi. hukum agar dapat menjawab permasalahan yang dibahas yang disajikan dalam bentuk deskriptif.

\section{HASIL DAN PEMBAHASAN}

1. Proses Pelaksanaan Pengembalian dan Pemulihan Kerugian Negara oleh Jaksa pada Tindak Pidana Korupsi

Proses Pelaksanaan Pengembalian dan Pemulihan Kerugian Negara Oleh Jaksa pada Tindak Pidana Korupsi, Mengenai prosedur yang dapat diterapkan untuk proses pengembalian/pemulihan kerugian negara atau pengembalian hasil tindak pidana berupa aset (Yanuar, 2007). berpendapat, berupa pengembalian aset/kerugian Negara dapat dilakukan melalui jalur pidana, perdata, dan administrasi atau politik. Berdasarkan pendapat Purwaning M. Yanuar, mengenai upaya yang dapat dilaksanakan saat mengembalikan kerugian Negara yang diakibatkan dari tindakan korupsi. Beberapa langkah dalam pengembalian dan pemulihan kerugian Negara akibat korupsi, sebagai berikut :

1. Pengembalian Kerugian Negara Melalui Proses Pidana

Melalui jalur pidana kejaksaan dapat melakukan tindakan-tindakan sebagai rangka mengembalikan kerugian negara dari tindakan korupsi yang dibuat koruptor, tindakan yang dapat dilakukan mulai dari tahap penyidikan hingga tahap eksekusi putusan dari hakim yang berkekuatan hukum tetap, tindakan-tindakan tersebut, antara lain :

a. Penelusuran Harta Kekayaan.

Penelusuran atau pelacakan harta uang kekayaan milik tersangka/terdakwa pelaku tindak pidana korupsi, menurut hukum acara pidana, upaya pelacakan berkaitan erat dengan tindakan penyelidikan dan penyidikan yang tercantum di pasal 1 butir 2 KUHAP. Ini dilakukan untuk memberi 
informasi penyelidik, penyidik, dan penuntut mengenai harta kekayaan tersangka/terdakwa sebagai upaya untuk mengembalikan kerugian uang negara.

Tujuan dari penelusuran harta kekayaan tersangka/terdakwa ini adalah untuk mengidentifikasi harta kekayaan, dimana penyimpanan harta kekayaan, alat bukti terkait kepemilikan atas aset, dan hubunganya dengan perbuatan yang dilakukannya.

\section{b. Penyitaan Aset/Harta Kekayaan}

Sesudah disusun/terkumpulnya keseluruhan informasi yang berkaitan dengan asset-aset hasil korupsi, barulah dilakukan penyitaan aset/harta kekayaan. Tindakan penyitaan tersebut bertujuan untuk mengamankan aset/harta kekayaan milik terdakwa/harta benda yang terhubung dengan korupsi terjadi, agar pengembalian pas dan sesuai pada pihak yang berhak sesuai putusan. Dalam praktek, istilah penyitaan aset/harta kekayaan oleh kejaksaan/penyidik lebih dekat dengan istilah pemblokiran, pemblokiran yang dilakukan oleh kejaksaan dalam rangka pengembalian kerugian negara dapat dilakukan terhadap rekening milik tersangka, sertifikat, surat-surat kendaraan dan barang-barang bergerak lainnya. Pemblokiran aset/harta kekayaan tersangka/terdakwa dilakukan mengenai harta benda dari tindakan korupsi dan harta yang dimiliki terdakwa tidak dari tindakan korupsi. Dan penyitaan terhadap harta kekayaan/aset yang dimiliki oleh tersangka dapat dilakukan terhadap harta kekayaan yang murni dari korupsi dan yang tidak murni dari tindakan korupsi.

c. Penuntutan Pembayaran Uang Pengganti

Langkah Kejaksaan dalam mengembalikan kerugian negara melalui jalur pidana dapat dilaksanakan dengan cara menuntut tambahan pidana mengenai pembayaran terhadap uang pengganti senilai dengan kerugian yang dialami Negara. Dalam prakteknya, jaksa penuntut umum harus bisa memposisikan pasal 18 UU pemberantasan Tindak Pidana Korupsi dengan pasal yang akan didakwakan kepada terdakwa, apabila tuntutan penuntut umum dikabulkan oleh hakim yang dicantumkan pada amar putusan dan sudah berkekuatan hukum tetap maka eksekusi dapat dilaksanakan.

d. Eksekusi/Melaksanakan Putusan Pengadilan Mengenai Pengembalian Kerugian Keuangan Negara

Setiap eksekusi putusan berada di tangan jaksa penuntut umum kewenangan, juga pada pidana uang pengganti, Untuk melakukan eksekusi, kejaksaan mengeluarkan surat perintah pelaksanaan putusan pengadilan. Selain melaksanakan perintah sebagaimana tersebut dalam putusan berkaitan pidana penjara, kurungan, pidana denda, barang bukti dan biaya perkara, kejaksaan juga melaksanakan putusan yang amarnya berisi pidana tambahan uang pengganti. Khususnya terhadap pidana membayar uang pengganti, tidak dibayarnya uang pengganti dapat dipidana. Kejaksaan yang melaksanakan eksekusi tidak akan langsung membuat berita acara pelaksanaan pidana pembayaran uang pengganti sebagai tambahan dengan subsider hukuman penjara terhadap terdakwa/terpidana yang lebih memilih dihukum penjara untuk mengganti atas uang pengganti. yang menetapkan jikalau jangka waktu satu bulan terdakwa tak melunasi uang pengganti maka dari itu harta bendanya dilelang dan disita oleh kejaksaan.

Harta kekayaan milik terdakwa yang berhasil disita tersebut akan dilelang dan uang hasil lelang dipergunakan untuk melunasi uang pengganti yang harus dibayar yang menjadi tanggung jawab terdakwa (Arsyad, 2013). Apabila uang hasil lelang belum cukup untuk menutupi pembayaran uang pengganti yang menjadi kewajiban terdakwa maka akan diperhitungkan berapa jumlah kerugian Negara yang masih menjadi tanggungan terdakwa dan berapa lama kemungkinan terdakwa harus mendekam di penjara sebagai upaya menganti atas tanggung jawab uang pengganti. Jika upaya pengembalian kerugian Negara melalui penyitaan harta kekayaan terdakwa tidak dapat dilakukan, melangsungkan hukuman penjara sebagai ganti atas tambahan pidana membayar uang pengganti.

1. Pengembalian Kerugian Negara Melalui lajur Perdata

Kerugian keuangan dan Pengembaliannya kepada Negara disebabkan tindak pidana korupsi dengan lajur perdata perdata. Apabila penyidik berpendapat dan memperoleh alasan bahwa lebih dari satu unsur tindak pidana korupsi tak mencukupi buktinya, namun telah ada suatu kerugian dari keuangan negara, maka berkas diserahkan oleh penyidik pada institusi yang merugikan untuk diajukan suatu gugatan. Saat proses pemeriksaan disidang pengadilan dilakukan namun terdakwa meninggalkan dunia ini, tapi secara riil kerugian uang Negara telah ada maka duplikat berkas acara 
berita sidang tersebut oleh penuntut umum segera diserahkan pada Jaksa Pengacara Negara atau Institusi yang mengalami kerugian untuk melakukan gugatan terhadap ahli warisnya secara perdata.

2. Pengembalian Kerugian Negara dengan Hukum Administrasi Negara

Pengembalian kerugian Negara Melalui Hukum Administrasi Negara menurut Arsyad (2015), pengembalian kerugian negara kekuasaan atau wewenang yang disalahgunakan untuk perbuatan korupsi, maka dapat mengakibatkan kerugian negara yang begitu besar pada keuangan suatu Negara. ada dua bentuk penyelesaian dalam ganti kerugian Negara tersebut, yakni berupa ;

a. Tuntutan Ganti kerugian

Kepada pegawai negeri tuntutan ganti kerugian dikenakan tidak bendahara/pejabat lain yang melakukan perbuatan melawan hukum karenanya, baik dengan sengaja ataupun kelalaiannya, menimbulkan terjadinya kerugian negara yang tidak berupa kekurangan perbendaharaan, dan kompetensi pembebanannya ada pada kementerian atau pemimpin lembaga bersangkutan.

b. Tuntutan Perbendaharaan

Tuntutan ini dikenakan kepada bendahara sebagai akibat perbuatan melawan hukum, baik sengaja ataupun kelalaian, telah menimbulkan terjadinya kekurangan perbendaharaan, kompetensi pembebanan ganti kerugian berada pada BPK. Secara singkat Upaya mengembalikan/pemulihan kerugian perekonomian negara suatu negara melalui pidana uang pengganti yang berdasarkan Keputusan Jaksa Agung Nomor : KEP-132/J.A/11/1994. dilakukan secara:

a. Dibuatkan surat penagihan (D-1) dengan perihal penagihan uang pengganti kepada terpidana untuk menghadap jaksa eksekutor di kantor kejaksaan setempat

b. Terpidana menghadap karena dipanggil jaksa eksekutor ditanya tentang kesanggupan membayar uang pengganti yang telah dijatuhkan oleh pengadilan yang telah berkekuatan hukum tetap. Pada tahap ini dibuatkan surat pernyataan (D-2) yang isinya sanggup atau tidak sanggup membayar uang pengganti. Apabila tidak sanggup membayar disertai dengan surat tidak mampu dari kelurahan/kepala desa

c. Setelah uang pengganti diterima dari terpidana maka Kejaksaan Negeri/Tinggi setempat membuat surat perintah (D-4) yang memerintahkan jaksa eksekutor/Kasi Pidsus/Kasubsi Penuntutan Pidsus untuk menyerahkan yang pengganti atas nama terpidana yang bersangkutan kepada Kasubagbin Kejaksaan setempat. Bendahara Khusus/penerima setelah menerima uang pengganti dalam waktu $1 \times 24$ jam harus menyetorkan uang pengganti dengan blanko Surat Setoran Penerima Negara Bukan Pajak (SSBB) ke kas Negara dengan mata anggaran penerimaan (MAP) 423473 melalui bank. Berdasarkan JAM BIN Nomor. 005/C/Cu/01/08 dan Permenkeu Nomor. 19/PMK.05/2007, MAP diubah menjadi Nomor 423614 berlaku sejak Januari 2008.

d. Terpidana tidak membayar uang pengganti maka harus ada bukti bahwa terpidana telah menjalani pidana pengganti. Hal ini harus dibuktikan dengan berita acara pelaksanaan hukuman pengganti (BA-8). Apabila terpidana sedang menjalani hukum atau telah menjalani hukuman pidana padahal berita acara pelaksanaan hukuman pengganti belum dibuat, maka Kejari harus memerintahkan Kasi Pidsus atau JPU koordinasi kepada Lembaga Pemasyarakatan untuk mendapatkan surat keterangan bahwa terpidana sudah menjalani hukuman pengganti. Surat keterangan harus dilampirkan dalam berkas perkara. Apabila pembayaran tidak dapat sekaligus dilakukan oleh terpidana, maka lebih mengarah kepada penyelesaian non litigasi yang dilakukan dengan negosiasi. Bahwa terpidana dapat membayar dengan cara mengangsur sesuai dengan kesepakatan sampai dengan lunas membayar uang pengganti.

\section{Upaya Pengembalian dan Pemulihan Kerugian Negara Akibat Korupsi}

Secara singkat penulis berpendapat suatu upaya yang dapat dilaksanakan oleh para penegak hukum dalam pemulihan kerugian negara akibat korupsi sebagai berikut :

1. Memaksimalkan Pengembalian Kerugian Negara dengan Upaya Penyitaan dan Penelusuran Harta Kekayaan Milik Terdakwa atau Terpidana.

Dalam pemberantasan tindak pidana korupsi yang menjadi prioritas bukan saja dengan dipenjaranya pelaku korupsi, namun juga harus diprioritaskan dikembalikan kerugian negara. Upaya yang dapat dilakukan oleh Para penegak hukum adalah melakukan kerjasama dengan pemerintah 
daerah dan pemerintah desa dimana terpidana tinggal dan menetap selama ini. Sehingga dapat diketahui dan di deteksi keberadaan harta-harta milik terpidana baik berupa tanah, bangunan, tempat usaha, tempat bekerja maupun harta lain yang bernilai ekonomis. Kejaksaan, KPK, dan Kepolisian, juga harus bekerjasama dengan pihak perbankan berkaitan dengan simpanan terpidana pada bankbank tertentu, dan bekerjasama dengan pihak SAMSAT dan Dinas Perhubungan guna menelusuri harta benda milik terdakwa dalam hal kepemilikan suatu kendaraan bermotor.

Penelusuran harta benda milik terpidana juga dilakukan terhadap saudara-saudara terpidana, keluarga terpidana dan rekan-rekan terpidana yang diduga mengetahui mengenai harta benda milik terdakwa. Tindak penyitaan yang oleh penyidik lakukan hanya terbatas harta benda yang memiliki hubungan atau hasil korupsi yang tersangka lakukan, sedangkan harta benda yang tak terkait dengan tersangka yang korupsi Cuma dilakukan pemblokiran saja untuk disita saat eksekusi jikalau terpidana tidak membayar atau melunasi uang pengganti sebagai tambahannya. Dan harta benda tersebut yang disita dan/atau yang dilakukan pemblokiran dapat disita dan dilelang kalau terpidana tidak membayar uang pengganti atau terpidana yang lebih memilih melakukan hukuman subsider daripada mengganti kerugian Negara.

2. Meyankinkan Terpidana Membayar Uang Pengganti

Walaupun dalam peraturan perundang-undangan, jika dengan putusan terpidana tak mampu membayar uang pengganti, maka bias dipenjara. Dan jaksa bias melelang harta kekayaan yang disita dari terpidana untuk menutupi kerugian negara, tetapi jika harta yang dilelang tidak memenuhi kerugian Negara yang disebabkan oleh terpidana, maka terpaksa terpidana harus menjalani pidana penjara sebagai ganti tidak membayar uang pengganti. Jika terpidana lebih memilih melaksanakan hukuman subsider daripada pembayaran uang pengganti, maka kejaksaan mengalami kendala dalam hal untuk mengembalikan kerugian negara kalau tidak mempunyai harta kekayaan yang dapat disita dari terdakwa untuk memenuhi kerugian.

3. Mengupayakan Masyarakat Mendukung Pemberantasan Korupsi

Salah satu elemen yang mempengaruhi penegakan hukum adalah masyarakat, sebab itu penegakan hukum yang baik harus melibatkan masyarakat untuk mewujudkanya. Karena sebaik apapun peraturan hukum dan bagus-bagusnya kualitas petugas dan kelengkapan fasilitas, kalau masyarakatnya yang yang terdampak peraturan tersebut tidak tumbuh kesadaran dalam dirinya untuk mematuhi peraturan tersebut, maka ketiga faktor tersebut tidak berguna.

4. Melengkapi Sarana dan Prasarana Untuk Pemberantasan Korupsi

Salah satu faktor yang mempengaruhi penegakan hukum antara lain Sarana atau fasilitas untuk mencakup kinerja manusianya yang berpendidikan dan terampil, terorganisasi, peralatan yang memadai, finansial yang cukup, dan sebagainya yang dalam hal ini kejaksaan dalam melakukan penyidikan/pemberantasan korupsi tidak memiliki alat penyadapan, hanya KPK saja yang mempunyai dan berwenang melakukan penyadapan tersebut. Tanpa a saran dan fasilitas yang mendukung, tidak mungkin ada penegak hukum yang dapat berperan dengan maksimal. Kejaksaan harus melakukan kerjasama dengan KPK yang memiliki alat penyadapan dan mempunyai kewenangan tersebut, sehingga dapat dimaksimalkan upaya pemberantasan korupsi yang terjadi. Sehubungan dengan alat penguji pekerjaan fisik terhadap proyek-proyek pembangunan fisik, sementara kejaksaan belum memiliki alat uji tersebut hanya meminjam dari pihak swasta atau instansi terkait yang memiliki alat uji tersebut serta mengandalkan kemampuan beberapa ahli untuk membantu mengungkap pekerjaan pembangunan fisik yang diduga ada penyimpangan dari pelaku. Dan juga kejaksaan secara dini melakukan koordinasi dengan pihak bank terkait untuk melakukan pemblokiran dan rekening harus dibekukan terhadap orang yang telah diduga terlibat dengan tindakan korupsi.

5. Kewenangan Jaksa KPK dan Penuntut Umum yang Diangkat dan Diberhentikan oleh KPK Harus Diatur Secara Tegas/Berdasarkan UU yang Berlaku

Kewenangan KPK hanya terkait penyelidikan, penyidikan, dan penuntutan, jadi disini adanya kekaburan norma yang tidak diatur secara tegas mengenai eksekusi putusan pengadilan mengenai tindakan korupsi yang dapat dilakukan eksekusi oleh KPK/Jaksa KPK maupun Penuntut Umum yang diangkat dan diberhentikan oleh KPK. Kewenangan atau tugas Penuntut Umum/Jaksa KPK harus diperjelas mengenai tugas dan wewenangnya dalam hal melakukan pemberantasan korupsi terkhususnya eksekusi putusan pengadilan mengenai perkara korupsi yang tidak diatur secara tegas. 


\section{SIMPULAN DAN SARAN \\ 1. Simpulan}

Prosedur pemulihan dan pengembalian kerugian Negara pada tindakan korupsi sudah sesuai prosedurnya berdasarkan aturan yang ada baik Undang-undang pemberantasan korupsi maupun aturan-aturan lain yang diberikan oleh Pemerintah, KPK dan Instansi-instansi yang berwenang, adapun prosesnya adalah, pengembalian/pemulihan kerugian Negara melalui jalur Pidana yaitu penelusuran harta kekayaan, penyitaan aset/harta kekayaan, penuntutan pembayaran uang pengganti, dan eksekusi/melaksanakan putusan pengadilan mengenai pengembalian kerugian Negara. Mengembalikan kerugian Negara dengan lajur Perdata. dan pengembalian kerugian Negara melalui Hukum Administrasi Negara berdasarkan Peraturan BPK Nomor 3 Tahun 2007, dan peraturan KPK Nomor 3 Tahun 2013 dan PP Nomor 38 Tahun 2016. Adapun upaya pemulihan kerugian negara dilakukan dengan memaksimalkan pengembalian kerugian Negara dengan upaya penyitaan dan penelusuran harta kekayaan milik terdakwa atau terpidana, meningkatkan kesadaran masyarakat mengenai bahayanya tindak pidana korupsi, memanfaatkan sarana dan prasarana yang ada, kewenangan Jaksa KPK dan Penuntut Umum diberhentikan dan diangkat KPK harus diatur secara tegas atau jelas berdasarkan Undang-undang yang berlaku/peraturan yang diterbitkan oleh Instansi yang berwenang/terkait.

\section{Saran}

Bagi Pemerintah harus memberikan sarana dan prasarana yang cukup bagi Kejaksaan dan KPK dalam rangka memaksimalkan pemberantasan korupsi dan pengembalian/pemulihan negara, baik bagi kejaksaan diberikan kewenangan untuk melakukan penyadapan maupun dalam bentuk atau cara lain yang mengikuti teknologi yang semakin canggih. Bagi Masyarakat sebuah dukungan masyarakat saat pemberantasan kasus korupsi dan mengembalikan/pemulihan kerugian uang Negara dari koruptor sangat diperlukan dengan menyampaikan informasi atau laporan ke Kejaksaan, KPK, dan Kepolisian terkait tindak pidana korupsi yang terjadi. dan bagi para pelaku tindak pidana korupsi sesegera mungkin mengembalikan kerugian negara baik dalam proses persidangan maupun berdasarkan putusan hakim, dan pelaku tindak pidana korupsi harus mempertanggungjawabkan perbuatan serta menyadarinya bahwasanya perbuatan korupsi begitu merugikan keuangan, dan perekonomian suatu Negara.

\section{DAFTAR PUSTAKA}

Arifin, F. (2019). Problematika Hukum Pengembalian Aset Tindak Pidana Korupsi Pelaku dan Ahli Warisnya. Pagaruyuang Law Journal, 3(1), 64-85.

Arsyad, J. H. (2013). Korupsi Dalam Perspektif HAN (Hukum Administrasi Negara). Sinar Grafika, Jakarta.

Arsyad, J. H. (2015). Korupsi Dalam Perspektif HAN (Hukum Administrasi Negara). Sinar Grafika, Jakarta.

Candra, D., \& Arfin. (2018). Kendala Pengembalian Aset Hasil Tindak Pidana Korupsi Transnasional. Jurnal BPPK, 11(1), 28-55.

Darmawati. (2020). Pengembalian Aset Kerugian Negara Perkara Korupsi Dalam Pemikiran Ius Constituendum. Jurnal Restorative Justice, 4(1), 87-100.

Hersriavita, S. (2019). Upaya Pengembalian Kerugian Negara dari Perkara Tindak Pidana Korupsi oleh Kejaksaan Negeri Sukoharjo. Jurnal Pasca Sarjana Hukum UNS, 7(1), 15-28.

Mahmud, A. (2018). Problematika Asset Recovery Dalam Pengembalian Kerugian Negara Akibat Tindak Pidana Korupsi Kajian Putusan Nomor 62/Pid.Sus/Tipikor/2013/PN.PBR. Jurnal Yudisial, 11(3), 347-366.

Musahib, A. R. (2015). Pengembalian Keuangan Negara Hasil Tindak Pidana Korupsi. Katalogis, 3(1), 1-9. Pengembalian Keuangan Negara Hasil Tindak Pidana Korupsi

Saidi, M. D. (2011). Hukum Keuangan Negara. Rajawali, Jakarta.

Yanuar, P. M. (2007). Pengembalian Aset Hasil Korupsi. Alumni, Bandung. 